\title{
ニューロマスキュラーデンティストリー入門
}

\section{2 機能的に調和した顎位の獲得のために}

高松 尚史 Hisashi Takamatsu

浜坂歯科医院（熊本県熊本市）

第1回 ニューロマスキュラーデンティストリーの治療の流れ

第2回 機能的に調和した顎位の獲得のために

第3回頢運動を記録する重要性

第4回 審美歯科への応用

はじめに

今日の歯科臨床において，歯と歯の接触状態つまり， 狭義の咬合状態を確認することは, 補緅修復治療のみな らず, 歯周治療やインプラント治療, および顎関節症の 治療など, 様々な場面で必要とされている. 第 1 回では, ニューロマスキュラーデンティストリーの理解の最初と して, 治療の流れを説明した. 顎口腔の機能は, すべて 下顎が動くことによって生ずる。身体と同じように左右 に同名の関節があり，筋があり，鞀帯がある。それらが 下顎の運動に関与するが, 下顎骨というひとつの骨で連 結されていて, 左右が勝手に動くことはない. ある部分 に不調和が生じれば, それにより全体のバランスが変わ ることになる，前回記したように，咬合再構成を行うに あたり，ニューロマスキュラーデンティストリーでは， 下顎の偏位の是正を優先する. 第 2 回となる今回は, そ のリファレンスポイントとしての生理的下顎安静位の理 解を深めたいと思う。

\section{下顎位について}

現在, 顎口腔系の異常に対する治療は, 可逆的治療に とどめるのが望ましいと言われている. しかし, 不可逆
的治療を否定しているのではなく, 症状の再発や顎口腔 系の異常の悪化を避けるために, 咬合治療を行う際には

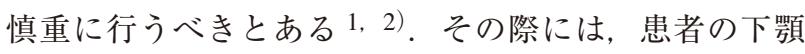
位を確認し，修正下顎位を決定する必要がある1)。当 然ながらその際に，患者の咬合状態が理論的理想咬合状 態 3) でないという理由で介入することはない. 患者が, 非生理的咬合状態や治療的咬合状態にある場合のみ, よ り生理的な状態へと復帰させることを目標とする.

現在では多くの臨床家が機能的咬合系の概念を理解し ている ${ }^{4)}$. 歯・顎関節・咀嚼筋が生理的に理想的な状態 にあれば問題ないが, それらに不調和が生じれば是正が 必要となる。 その際, やみくもに修正を行うことは科学 的ではない，是正するための目標が必要となる.

現在の下顎位の区別は，以前ほど明確に分かれるもの ではないように思われる. しかし，機能的咬合系のどの 部分を中心に考えるかによって，分類できる（図1）.

\section{(1)中心位}

2017 年 5 月に発表された米国歯科補綴用語集の最新

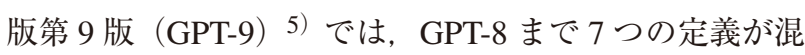
在していたものが, 23 年ぶりにようやく 1 つの定義に 集約した，顆頭は，関節隆起の後部斜面に対して，前上 方位置にある位置とした。しかし，この定義は関節円 
板の位置が正常な状態を前提としている．関節円板は 18 ～ 50 歳で 28 〜 $50 \%$ の人に転位があるという報告 6) があり，この定義に当てはまらないこともある。，一方， 下顎頭については, 顕著に形態変化が生じる部分であり, 機械的負荷に反応してリモデリングが生じ, 構造変化が 生じる 1).これらのことからニューロマスキュラーデン ティストリーでは, 顎関節の動態を理解しながら治療を 進めるものの, 基準位としては利用しない. また現在で は, 中心位を基準に咬合再構成する場合でも, 咀嚼筋の 緊張を緩和して生理的な状態にすることを重要視する臨 床家も多い7).

\section{(2)筋肉位}

歯を失った総義歯の臨床において, 咬合採得は誰でも 同じように行っているはずである. 歯の存在がないため に，ろう堤を用い，咬合採得を行う。また，総義歯でさ えも，粘膜の動きにより，見かけ上はきれいに嵌合して いるような錯覚を得る場合がある。このときも，人工歯 の接触を避けるように中心咬合位でチェックバイトを採 得し, リマウント調整することが望ましい8). 歯が存在 する場合, 咬合接触様式は違っても, 同じょうな咬合採 得を行うことが大切ではなかろうか. 1959年にBrill ら9) が筋肉接触位 (Muscular Contact Position, MCP), 1968 年にKrogh-Poulsen ${ }^{10 ）}$ が筋肉位（Muscular Position, MP）を提唱した（図 2). 両者の提唱する下顎位は, 下 顎運動の原動力である咀嚼筋群に焦点を当て, かつ咀嚼 筋群が, 機能的にバランスがとれてこそ最も生理的な位 置が求められるとした ${ }^{11)}$. いずれの場合でも2つの点 が重要である.1つ目は咀嚼筋が機能的に安定した状態
にあることであり，2つ目は下顎安静位から最小の筋活 動により閉口することである。

\section{生理的下顎安静位とは}

下顎安静位（rest position）は, 重力の影響を受ける ため頭位に影響を受けることは周知のことである。 山下 ら11）は，下顎安静位について「上半身直立の姿勢をと り, 精神的に安静な状態にある時の下顎位で, 下顎が重 力と筋緊張の均衡した状態においてとる安定した位置と 考えられ，拮抗筋の働きによって体幹の姿勢が保たれる ように，開閉口筋のバランスによって保持される下顎の 位置であるため姿勢位 (postural position) ともよばれる」 と述べている，つまり，筋肉位を採得するにあたり，直 立した頭位においての下顎安静位を利用しなければ，そ のスタート地点がずれることとなる.

また，咬合治療を行う患者は，問題のある箇所からの 回避行動や自然と構築された咀嚼癖などの様々な筋活動 の異常が認められる。通常, 下顎安静位は咀嚼運動の効 率化から, 咬頭嵌合位の直下に位置づけられるため, 下 顎の偏位が認められる患者では, 下顎安静位も偏位して いることがある，その場合，安静位であっても咀嚼筋群 に緊張が生じ，さまざまな症状を惹起する原因にもな る（図 3，4）、下顎安静位が必ずしも最小の筋活動を行 っているとは限らないのである。一方, 顎口腔機能診断 装置（K7 Evaluation System：Myotoronics 社, 以下 K7） にて記録すると，下顎の偏位に下顎安静位が順応してい ない患者も見受けられる。 その場合, 無意識のうちに咀 嚼運動などを行うときにだけ，偏位しながら顎運動を行

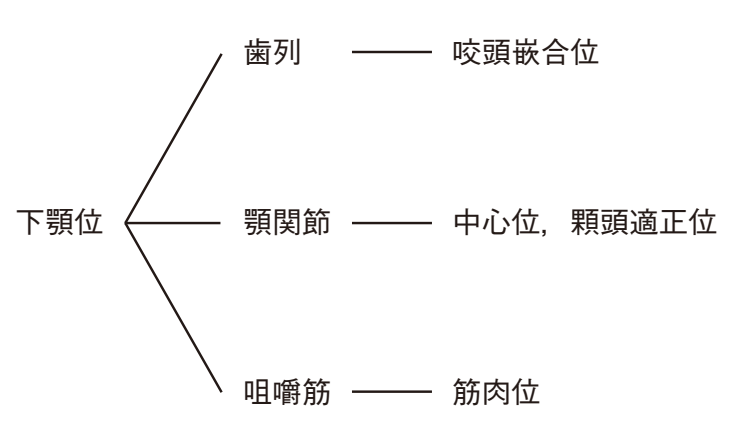

図1 下顎位の基準を何に求めるか

\author{
Muscular Contact Position (Brill.N, et al. 1959) \\ 咀嚼筋が機能的にバランスがとれた状態で、下顎位が安静 \\ 位付近からゆっくりと最小の筋力で閉口した時の咬合位 \\ Muscular Position（Krogh - Paulsen WG, 1968） \\ 筋が機能的に安定した状態で、下顎安静位付近から静かに \\ 閉口した位置
}

図2 Brillらの筋肉接触位 (Muscular Contact Position, MCP) と Krogh-Poulsenの筋肉位 (Muscular Position, MP) 
っている (図 5～7). ニューロマスキュラーデンティ ストリーでは, 筋リラクセーションを獲得した後（図 4) の下顎安静位を「生理的下顎安静位 (physiologic rest position)」と呼び, 必ず, 筋リラクセーション後（図 8) の生理的下顎安静位をリファレンスポイントとして利

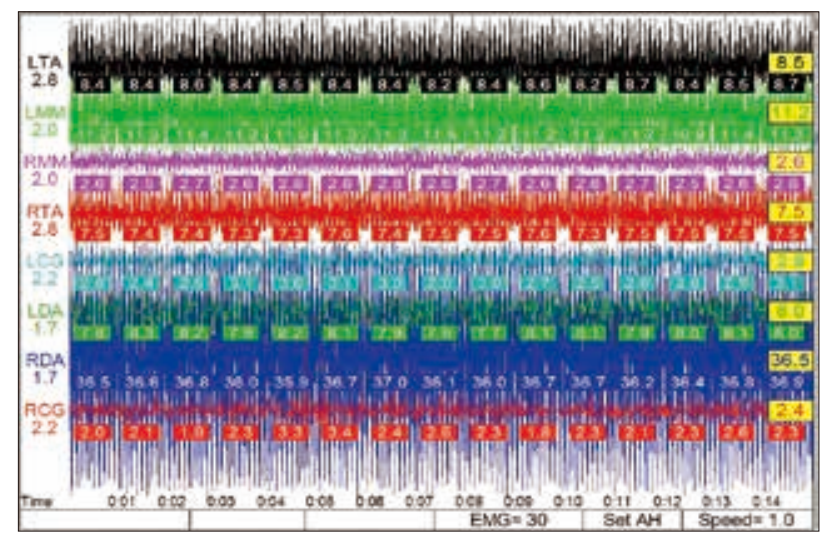

図3 下顎安静位における筋電図（咬笳・側頭筋前部・顎二腹 筋前腹・耳後部)

正しい姿勢で下顎安静位をとっているにもかかわらず，筋肉の 緊張がうかがえる. 患者にはさまざまなTMD症状が生じている.

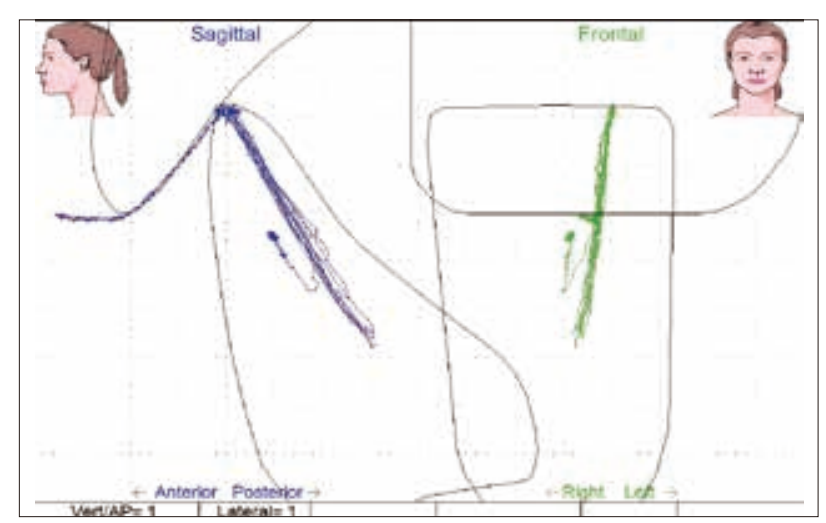

図5 下顎安静位と開閉口運動の軌跡

正しい姿勢で下顎安静位から開閉口運動と前方運動を行ってい る. TENSを使用する前のデータであるので, 患者の現在の状 況を現している. 下顎安静位が咬頭嵌合位の直下に位置づけら れていない. 患者には, TMD症状はみられない.

図7図5の患者を筋肉位で治療後, 図6と同じ方法でデータ を採得した

下顎安静位と開閉口運動の位置関係が良好になっているのが わかる. ニューロマスキュラーデンティストリーの下顎位で の目標である.
用している. GPT-9 5) では, rest position = physiologic rest position $=$ rest vertical dimension と記載されており, 「直立姿勢で快適に休んでいて, 関連する筋肉が最低限 の活動の状態にあるときの下顎の姿勢」とある.

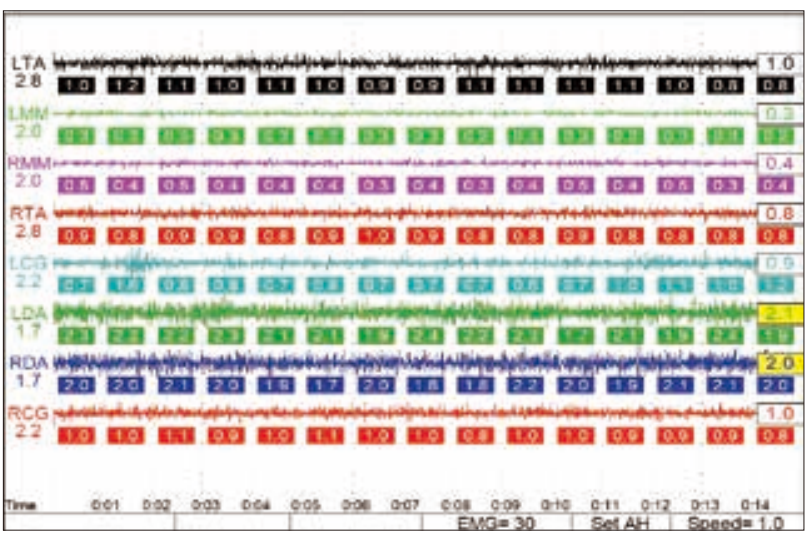

図4 TENSを45分間使用した後の下顎安静位における筋電図 表面電極の位置を変えることなく，図3の患者にTENSを使 用後に測定している. 同じ患者とは思えないほど, 筋肉のリ ラクセーションが獲得できている

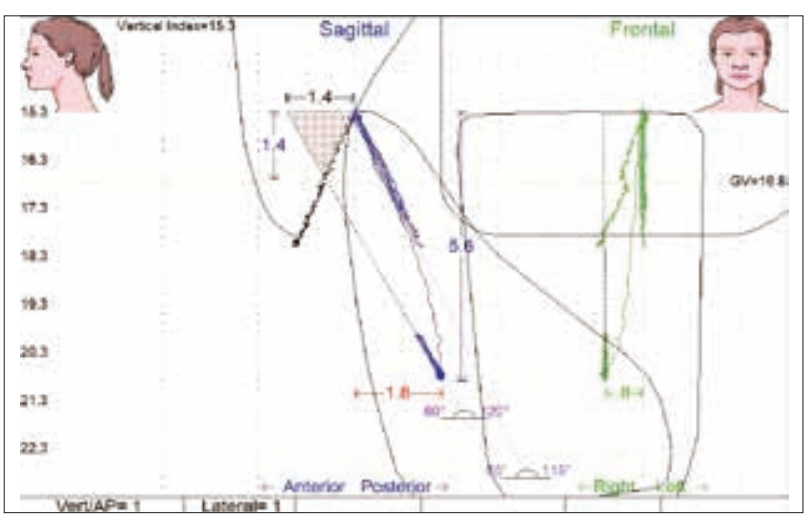

図6 図5の患者にTENSを使用後に同じデータを採得した

下顎安静位と咬頭嵌合位の位置関係が，図5とほぼ同じ状況に あるのがわかる.

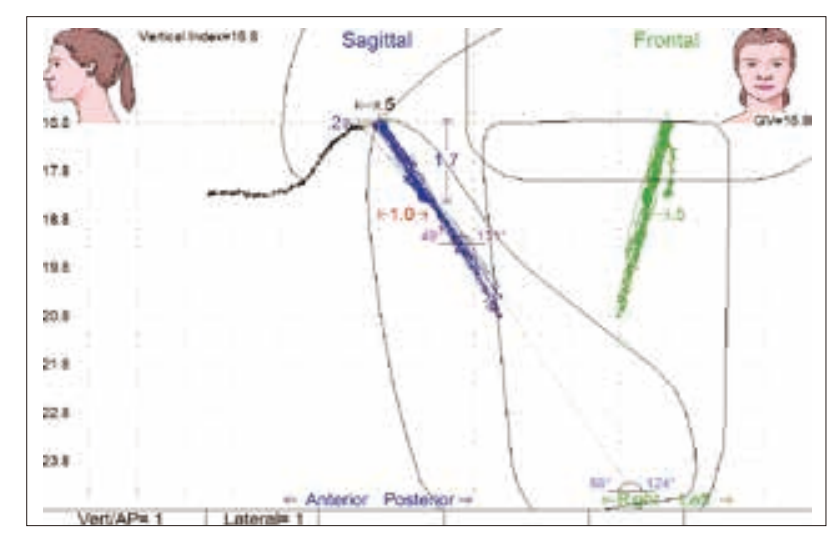




\section{生理的下顎安静位を求めるには}

咀嚼筋群の過緊張等による不安定な下顎安静位を安定 させる方法には下記の方法がある ${ }^{11)}$.

1. 薬剤

2. バイオフィードバックコントロール

3. スプリント

4. 歯科用経皮的電気神経刺激装置 (Transcutaneous Electrical Neural Stimulation, 以下 TENS)

ニューロマスキュラーデンティストリーでは, 一般医 療で用いられる TENS を使用している。TENS には大き く分けて 2 種類あり ${ }^{12)}$, 使用する TENS はその中でも 超低周波 TENS（Ultra-low frequency TENS）と考えら れる. その理学的性質の一部を下記にあげる。咀嚼筋群 の過緊張等を緩和し, 生理的下顎安静位獲得に有利に働 くと考える.

(1)顎関節機能障害とそれに伴う疼痛を治療す る $13 \sim 16)$

(2)筋肉のれん縮に関連する症状を緩和する 13，17)

(3)筋肉を弛緩させ, 生理的咬合を確立す る $13,14,17 \sim 19$ )

(4)局所血行を促進する20〜23)

(5)下顎可動域を維持または増加させる 24)

GPT-9 5) では, この TENS を Myo-monitor として紹 介している (図 9)。これによる刺激経路については様々

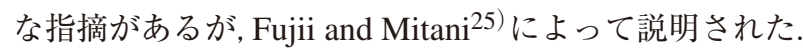
ニューロマスキュラーデンティストリーでは, 目指 す下顎位として，この TENSによって生理的下顎安静 位を獲得し，筋肉の最小の力で閉口した位置を求め,
Neuromuscular Position（以後, NP）と呼ぶ（当初は, Myocentric と呼び, GPT-9 にもそのように記載されて いるが, 最近では, NP と呼ばれている).

\section{症例}

\section{(1)初診}

36 歳, 女性. 2001 年全顎治療を主訴に来院した. 既 往歴として, 小学校のころ4 治療後, 高いと感じるが そのままにしていたと記憶している，高校生のころにク ローズドロックを経験する，大学生のころに歯科大学に てスプリント装着. 現在は, 2,3 カ月に 1 回頭痛があり, 内科では偏頭痛の診断を受ける。軽い開口障害があり, 右側顎関節部の痛みや雑音がある。口腔内所見では，臼 歯部に多くの修復物があり，ハイブリッドセラミック前 装冠の咬耗がある，左側に欠損があるだけで，歯列の不 正は大きくないが, 側方面観にて, 犬歯と小臼歯の咬頭 の高さの不調和があり， 兒歯部咬合高径の低下が予想さ れる（図 10, 11）。

\section{(2) Phase1 可撤式スプリント作製}

K7 にて, 現在の下顎安静位と開閉口運動の軌跡を記 録すると, 下顎安静位が前方に位置し, 開閉口運動の時 に後方へ偏位していることがわかる（図 12）。さらに, その下顎安静位での筋電図を採得すると, 側頭筋前部 や顎二腹筋前腹に緊張が認められる（図 13）。45 分間 TENS を使用したあと，筋のリラクセーションを確認し (図 14), 生理的下顎安静位から, 閉口した位置で可撤
下顎安静位 $\neq$ 筋リラクセーション

生理的下顎安静位 $=$ 筋リラクセーション

\section{図8 生理的下顎安静位}

既存の下顎安静位で必ず筋リラクセーションが獲得 できているとは限らない. 必ず，生理的下顎安静位 をリファレンスポイントとして，筋肉位を採得しな ければならない.
・1969年にJankelsonによって導入された，筋リラクセー ションを行い咬合位を得るために, 顎口腔系の両側経皮 的電気神経刺激用に特に最適化されたデジタル電子パル 又発生器 (GPT-9)

・持続時間約 $0.5 \mathrm{msec}$, 電圧11～22Vの矩形波 パルスを1.5secに1回の頻度で発射する.

・第Vならびに第VII脳神経幹を経皮的に電気刺激する.

・筋のリラクセーション他, 多くの効果を得られる 

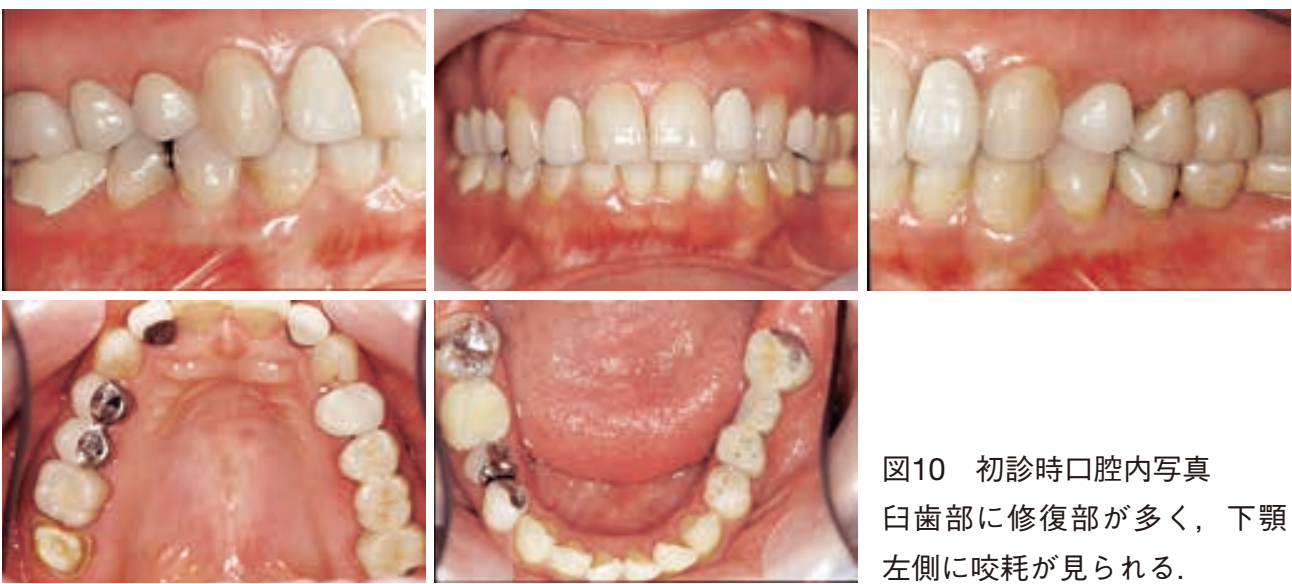

図10 初診時口腔内写真

臼歯部に修復部が多く，下顎 左側に咬耗が見られる.

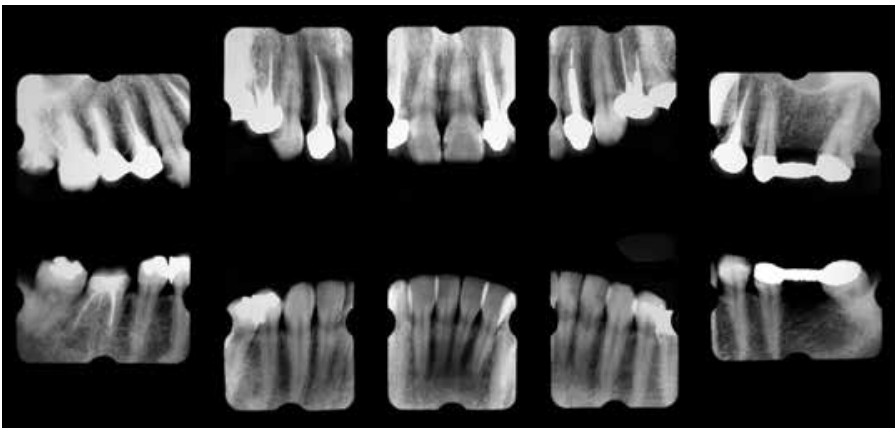

図11 初診時エックス線写真

図12 下顎安静位と開閉口運動の軌跡

下顎安静位が, 開閉口運動の軌跡より前方に位 置しているのがわかる.

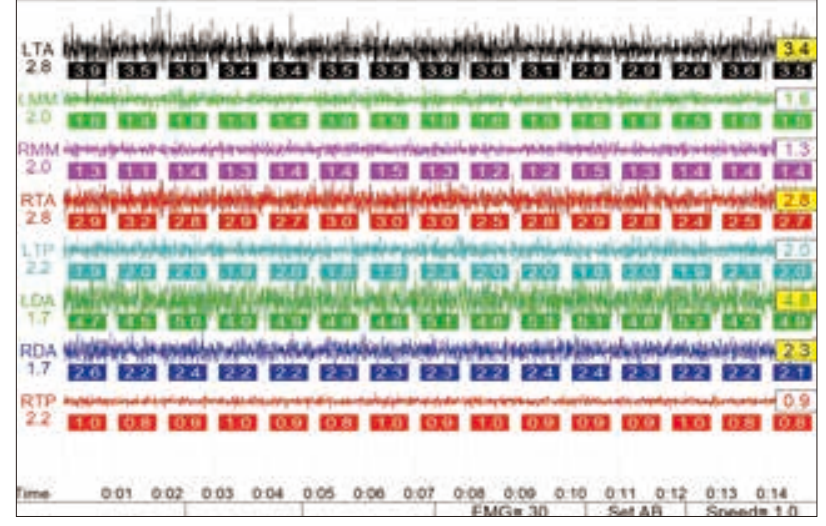

図13 下顎安静位における筋電図（咬筋・側頭筋前部・顎二腹 筋前腹 $・$ 耳後部)

側頭筋前部や顎二腹筋前腹に緊張が認められる.
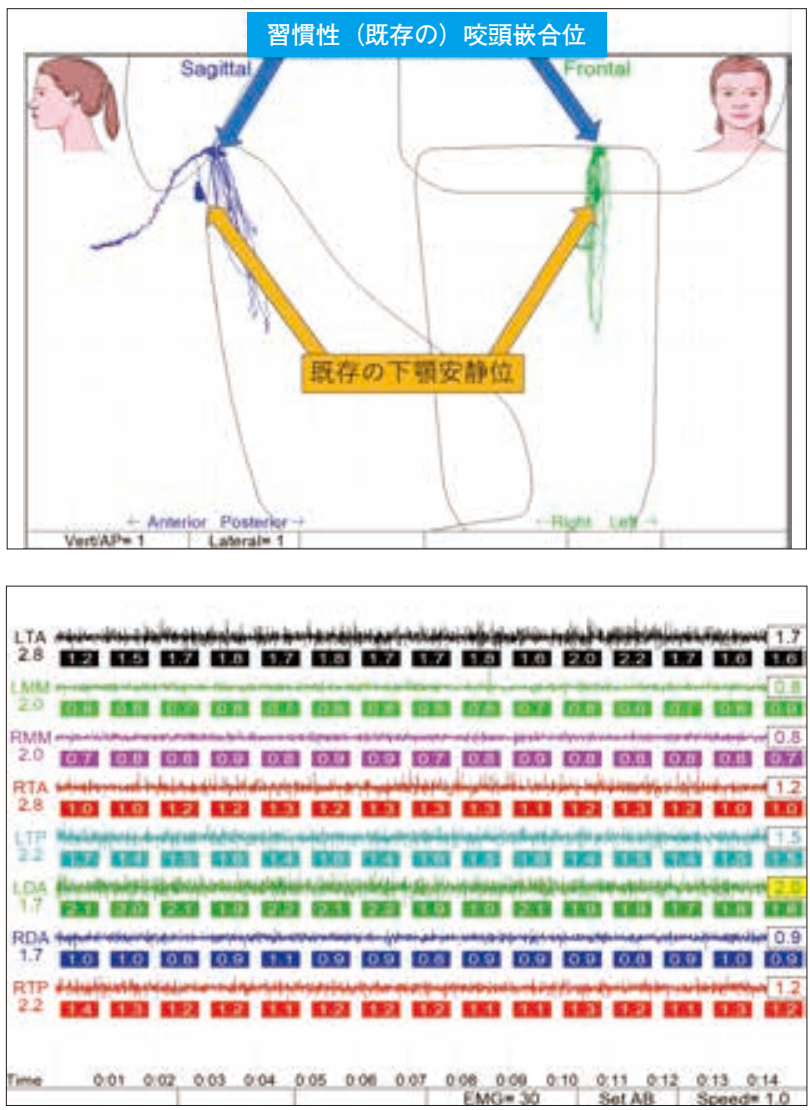

図14 TENS使用後の下顎安静位における筋電図

筋のリラクセーションが確認できる. 


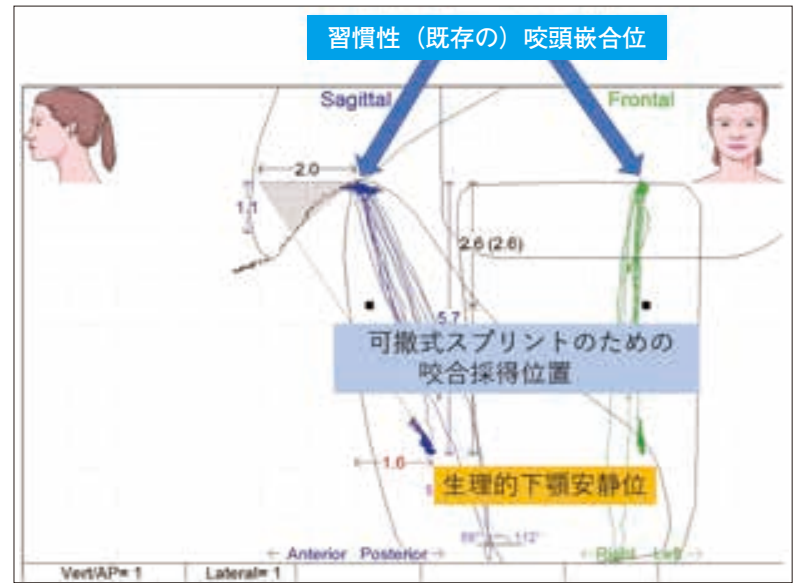

図15 可撤式スプリントのための咬合採得

生理的下顎安静位から，閉口した位置で咬合採得を行う。
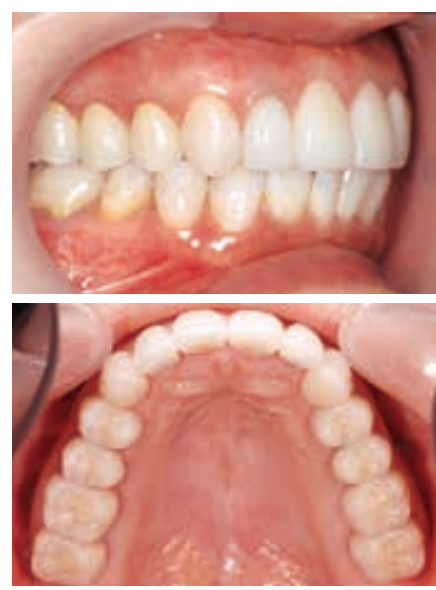
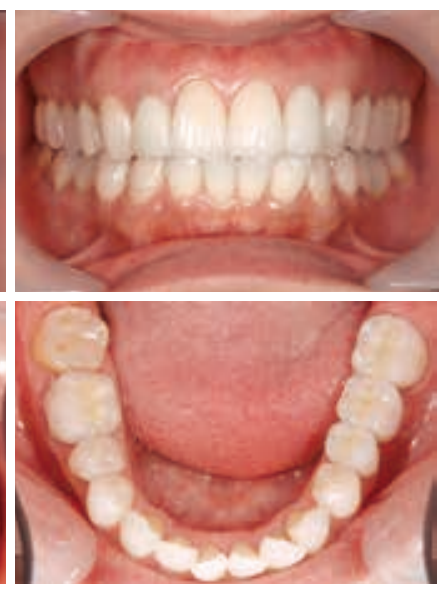

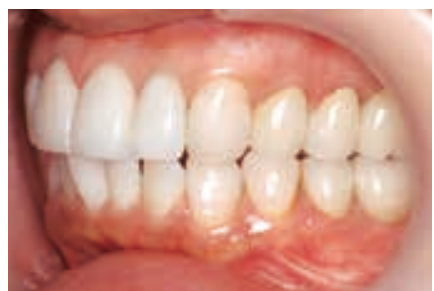

図16 最終補緅物装着後口腔内写真

上顎前歯部にオールセラミッククラウン（エンプレス ${ }^{\circledR}$, Ivoclar Vivadent社），上顎犬歯と下顎小臼歯部にオール セラミックアンレー（エンプレス ${ }^{\circledR}$ ， Ivoclar Vivadent社）， 上顎臼歯部と下顎大臼歯部に陶材焼付け前装冠を装着した.

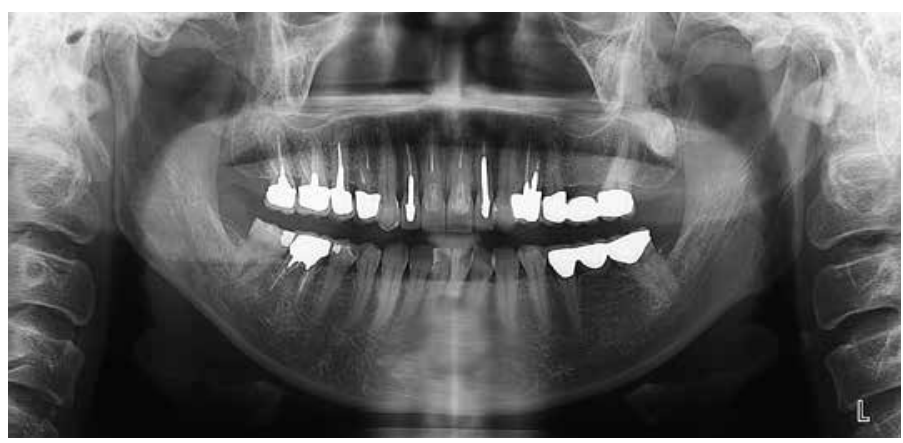

図17 パノラマエックス線写真

式スプリントのための咬合採得を行った（図 15）.

症状の改善を目的に食事以外の装着を勧めた．6力月 程度の経過観察し, 様々な症状はほとんど消失したため, 修復治療に移行することとした。

(3) Phase 2 修復治療

再度, 生理的下顎安静位から閉口した位置で咬合採得 を行い, プロビジョナルレストレーションを装着した。
その後, 微調整を行い，K7にて確認を行い，次のステ ップに移る。最終補綴物装着後（図 16，17），再度 K7 にて確認を行う（図 18）。この患者は，以後も症状はな く, 修復治療終了後 15 年以上が経過している（図 19）. この症例からも, 生理的下顎安静位から, 静かに閉口し たNPは，長期的に症状を惹起することなく，安定した 咬合状態を維持することがうかがえる. 


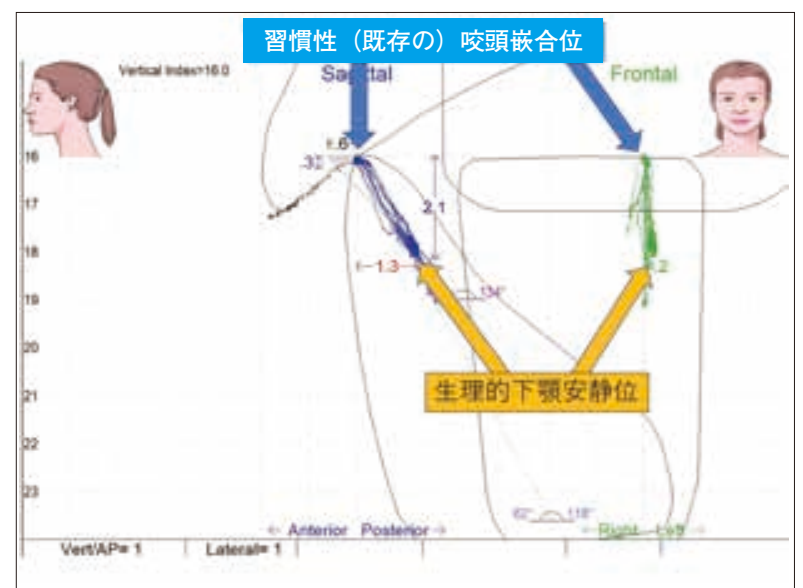

図18 術後 Scan 5

生理的下顎安静位と咬頭嵌合位，そして開閉口運動 が正しい位置で機能している.

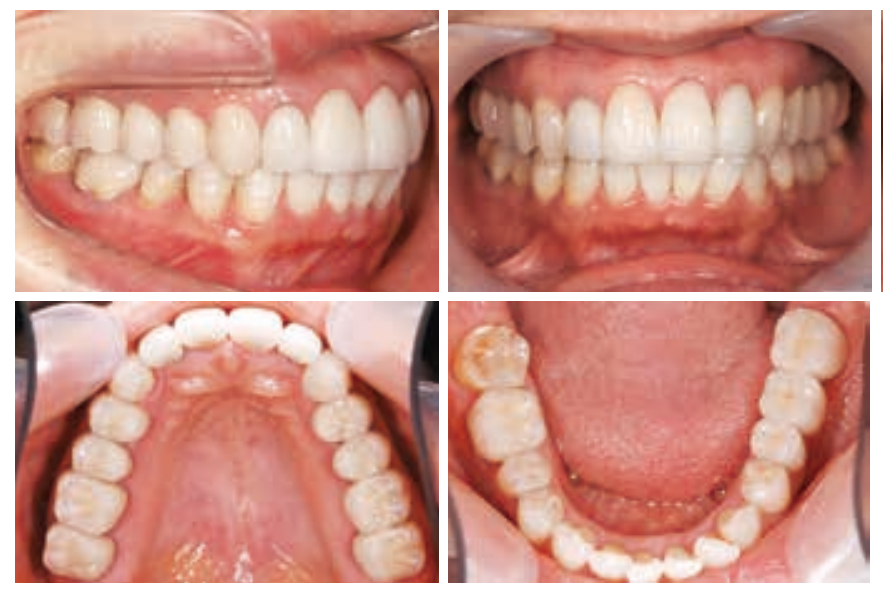

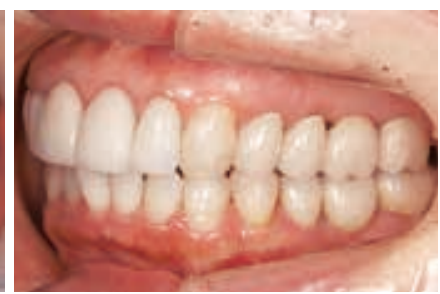

図19 術後15年経過, 口腔内写真 歯肉の炎症や修復物の着色, アンレー接着面 の着色が多少見られるが, 破折などもなく, 咬耗も少ない.

\section{まとめ}

治療を行うにあたり，すべての症例において下顎の偏 位があるとは限らない. しかし, その可能性があるので あれば, 最初に下顎の偏位を疑い, 診査・診断すべきで ある。ニューロマスキュラーデンティストリーでは，下 顎安静位から閉口した位置を目指すのではなく, 筋リラ クセーションを獲得した生理的下顎安静位をリファレン スポイントとしている。一般臨床家においては, TENS

\section{参考文献}

1）日本顎関節学会編: 顎関節症: 永末書店(東京), 2003.

2）日本顎関節学会編: 新編 顎関節症: 永末書店(東京), 2013.

3) Mohl ND, Zarb GA, Carlsson GE, ほか(著), 藍稔(訳): テ キストブックオクルージョン:クインテッセンス出版(東京), 1993.

4) 河村洋二郎: 口腔生理学: 永末書店 (京都),1966.

5) The Academy of Prosthodontics: The Glossary of
を使用することに懐疑的な意見や，NP はより前方に咬 頭嵌合位が求められるといった意見もある. それぞれは, この理論を十分に理解していないことによる偏見であろ う. 現実に長期安定症例が多数存在し，半世紀にわたり 変わらぬ概念で使用されていることは特筆すべきことと 考える.

次回は, ニューロマスキュラーデンティストリーの根 幹をなす，顎運動・筋電図を記録する重要性を説明した いと思う.

Prosthodontics Terms, 9th edition. J Prosther Dent 2017: Volume 117 Issue 5S, e20.

6) Okeson JP(著), 藤本順平, 山本健一, 岡野昌治ほか (監 修): 口腔顔面痛の鑑別診断と治療. 歯界展望, 97(2): 301322, 2001.

7）岩田健男：理想咬合像から臨床咬合像への変遷：咬合 YEARBOOK 2016. クインテッセンス出版(東京), 2015. 
8）黑岩昭弘: 無歯顎の咬合採得〜簡単で効果的な顎位決定 方法～. 日歯医師会誌, $167(11):$ 47-56, 2015.

9) Brill N, Lammie GA, et al.: Mandibular positions and mandibular movement. Brit Dent J, 106: 391-400, 1959.

10) Krogh-Poulsen, WG: Management of the Occlusion of the teeth. In Facial Pain and Mandibular Dysfunction, edited by Schwarlz, L. and Chayes, C. H.: 236-280, WB Sanders(Philadelphia), 1968.

11）山下敦, 矢谷博文, 窪木拓男: 最新生理咬合学と顎関節症 の治療: クインテッセンス出版(東京), 1993.

12) Jankelson R: Neuromuscular dental diagnosis and treatment, Ishiyaku EuroAmerica (St. Louis), 1990. 2005.

13) Cooper B, Kleinberg I: Establishment of temporomandibular physiological state with neuromuscular orthosis treatment affects reduction of tmd systems in 313 patients. Cranio, 26(2):104-117, 2008.

14) Cooper BC: The role of bioleectronic instrumentation in the documentation and management of temporomandibular disorders. Oral Surg Oral Med Oral Pathol Oral Radiol Endod: 83 (1): 91-100, 1997.

15) Ferreira AP, Costa DR, Oliveira AL, et al:: LR Shortterm transcutaneous electrical nerve stimlation reduces pain and improves the masticatory muscle activity in temporomandibular disorder patients: a randomized controlled trial. J Appl Oral Sci, 25 (2):112-120, 2017.

16) Wessberg G, Carroll W, Dinham R, et al.: Transcutaneous electrical stimulation as an adjunct in the management of myofascial pain-dysfunction syndrome. J Prosthet Dent, 45 (3) : 307-314, 1981.

17) Monaco A, Sgolastra F, Ciarrocchi I, et al.: Effects of transcutaneous electrical nervous stimulation on electromyographic and kinesiographic activity of patients with temporomandibular disorders: a placebo-controlled study. J Electomyogr Kinesiol, 22 (3) : 463-468, 2012.
18) Eble OS, Jonas IE, Kapppert HF: Transcutaneous electrical nerve stimulation (TENS): its short-term and long-term effects on the masticatory muscles. J Orofac Orthop: 61 (2): 100-111, 2000.

19) Bazzotti, L : Electromyography tension and frequency spectrum analysis at rest of masticatory muscles before and after TENS Electromyogr Clin Neurophysiol, 37 (6) : 365378, 1997.

20) Kamali F, Mirkhani H, Nematollahi A, et al.: The Effect of Transcutaneous Electrical Nerve Stimulation of Sympathetic Ganglions and Acupuncture Points on Distal Blood Flow. J Acupunct Meridian Stud, 10(2):120-124, 2017.

21) Meyerspeer M, Mandl T, Reichel M Mayr, et al.: Effects of functional electrical stimulation in denervated thigh muscles of paraplegic patients mapped with T2 imaging. MAGMA, 21 (3): 219-226, 2008.

22) Cosmo P, Svensson H, Bornmyr S, et al.: Effects of transcutaneous nerve stimulation on the microcirculation in chronic leg ulcers. Scand J Plast Reconstr Surg Hand Surg, 34(1):61-64, 2000.

23) Evans DR, Williams KJ, Strutton PH, et al.: The comparative hemodynamic efficiacy of lower limb muscles using transcutanteous electrical stimulation. J Vasc Surg Venous Lymphat Disord, 4(2):206-214, 2016.

24) Kato MT, Kogawa EM, Santos CN, et al.: TENS and low-level laser therapy in the management of temporomandibular disorders. J Appl Oral Sci, 14(2): 130135, 2006.

25) Fujii H, Mitani H: Reflex responses of the master and temporal muscles in man. J Dent Res, 52: 1046-1050, 1973. 